\title{
KATSE MUIHIN POHJOISMAIHIN
}

Vuosi 2020 tullaan muistamaan muun muassa Brexitistä, tapaus Aleksei Navalnyistä, Valko-Venäjän tapahtumista ja Yhdysvaltain kaoottisesta yhteiskunnallisesta tilanteesta dramaattisine presidentinvaaleineen sekä Suomen sisäpolitiikassa Sanna Marinin - maamme ensimmäisen sosialidemokraattisen naispääministerin - johtaman, keskipuolueilla täydennetyn punavihreän hallituksen ja oikeisto-opposition keskinäisistä kiivaista mielipiteenvaihdoista.

Ennen muuta vuosi 2020 jää kuitenkin koko maailman muistiin murheen vuotena, jolloin kaikkia kansakuntia kohtasi koronavirus ja sen aiheuttama, pandemiaksi äitynyt, pahimmillaan tappavaksi kehittyvä covid-19-tauti. Pandemian hillitsemiseksi maailman valtiot ovat tehneet erinäisiä ratkaisuja, ja pieneltä osaltaan ne ovat vaikuttaneet myös nyt käsillä olevaan Työväentutkimus Vuosikirjaan. Yksi kaavailluista artikkeleista jäi pois syystä, että arkistot olivat suljettuina keväällä, ja niinpä kirjoittajan työskentely keskeytyi. Ja nyt marraskuussa jäi pitämättä Kööpenhaminassa järjestettäväksi tarkoitettu pohjoismainen työväenhistoriakongressi. Käsillä oleva julkaisu oli teemansa vuoksi tarkoitus esitellä myös kyseisessä tapahtumassa, minkä myötä viisi artikkelia julkaistaan alkuperäisen tehtävänannon mukaisesti englanniksi. Vuosikirjamme äärellä pohjoismaiset lukijat voivat siten tutustua kansainvälisen erikoisnumeromme "pohjoismaiseen antiin" puolueettomalla kielellä.

Teemanamme on tänä vuonna "Katse muihin Pohjoismaihin". Historiallisista ja maantieteellisistä syistä Suomen työväenliikkeen yhteydet muihin Pohjoismaihin ovat useimmiten tarkoittaneet siteitä erityisesti lähimmän naapurimme Ruotsin työväenliikkeeseen, vaikka eri tason kontaktit myös Norjan, Tanskan ja Islannin työväenliikkeisiin ovat vuosikymmenten saatossa ilahduttavasti nekin tiivistyneet. Tämänkertaisen julkaisumme teemaan kytkeytyvät artikkelit kertovat siitä, miten siteet juuri Ruotsiin voivat ilmetä mitä erilaisimmissa suomalaistutkijoiden hankkeissa. Aiheina ovat ensinnäkin Suomen ja Ruotsin sosialidemokraattisten puolueiden ideologinen kehitys sekä Suomessa 1970- ja 1980-luvuilla sosialidemokraattien ja ay-liikkeen keskuudessa käyty keskustelu ruotsalaisesta palkansaajarahastomallista. Kirjoittajina ovat tohtorit Sami Outinen ja Ilkka Kärrylä. Ruotsin suomalaissiirtolaisten EEC-käsityksiä 1970-luvulla teatterinäytelmien ilmentäminä tarkastelee puolestaan dosentti MikkoOlavi Seppälä.

Kuluvana vuonna tuli kuluneeksi sata vuotta sosialidemokraattien vasemmalla puolella olevan työväenliikkeemme kotimaassa tapahtuvan toiminnan alkamisesta. Niinpä tarjolla on myös dosentti Tauno Saarelan katsaus toukokuussa 1920 aloittaneen Suomen sosialistisen työväenpuolueen vaiheisiin. Tri Matias Kaihovirran kirjoittamassa artikkelissa on puolestaan esillä Karl Harald Wiikin vaikutus kansallisuuskysymyksen tarkasteluun Suomen sosialidemokraattisessa puolueessa 1900-luvun alkupuoliskolla. Tutkijan luupin alla on lisäksi vuonna 1984 säädetty työttömyysturvalaki, josta kirjoittaa FM Maija Absetz, Freelancetoimittajien työmarkkina-aseman kehitystä takavuosina tarkastelee YTM Pentti Peltoniemi. Julkaisumme artikkeleiden aiheskaala on jälleen laaja, kuten on laita työväentutkimuksessa ylipäätään.

Katseen muihin Pohjoismaihin suuntaamme myös Keskustelua-osiossa, jossa Tanskan työväenmuseon johtaja Søren Bak-Jensen ja Norjan työväenliikkeen arkiston ja kirjaston johtaja, Dr. Ole Martin Rønning tarkastelevat johtamiensa laitosten tämänhetkisiä kuulumisia. Tavanomaiseen tapaan esittelemme tekijöidensä laatimin abstraktein muutamia uusia pro gradu -tutkielmia sekä tarjoamme laajan kattauksen kirja-arvioita työväentutkimuksen piiriin kuuluvista uusista teoksista. Työväen perinnelaitokset kertovat nekin jälleen kuulumisiaan.

Kiintoisia lukuhetkiä ja toivon mukaan parempaa ensi vuotta toivottaen

Erkki Vasara

päätoimittaja

erkki.vasara@helsinki.fi 